\title{
PROBLÉMÁK ÉS PERSPEKTÍVÁK: „MI A TEENDŐ” A KIALAKULÓBAN LÉVÖ KRITIKAI GEOGRÁFIA SZÁMÁRA MAGYARORSZÁGON? ${ }^{1}$
}

\author{
(Problems and Perspectives: "What's Left" for Emerging \\ Critical Geography to do in Hungary? \\ TIMÁR JUDIT
}

Kulcsszavak:

kritikai földrajz egyenlötlen területi fejlödés társadalomelméletek alkalmazott földrajz „népföldrajz"

A Békéscsabán megrendezett 3. Nemzetközi Kritikai Geográfiai Konferencia szembesítette a hazai résztvevōket azzal a ténnyel, hogy Magyarországon a kritikai geográfia még csak a megszulletés fázisában van. E tanulmány ezért arra a kérdésre keresi a választ, milyen teendöi lehetnek a hazai és a nemzetközi kritikai geográfia képviselöinek, hogy megerösitsék ezt az irányzatot. Elöször történelmitársadalmi összefüggésben kisérel meg néhány lehetséges magyarázatot felvillantani arra a kérdésre, hogy: vajon miért nem bontakozott ki kritikai geográfiai mozgalom Magyarországon. Az okokat azonban nemcsak a szocialista, poszt-szocialista társadalmi-gazdasági környezetben, s nemcsak a magyarországi akadémiai intézményrendszer változásaiban keresi, de a nemzetközi kritikai, illetve korábbi radikális geográfia felelösségét, a kritikai elméletek néhány hiányosságát is felveti. Végül néhány javaslatot fogalmaz meg a ,teendökre" vonatkozóan.

„Milyen teendő maradt?" ("What's left to do?") A kérdést Dick Walker tette fel 1989-ben egy olyan izgalmas vitát indítva az Antipode c. radikális földrajzi folyóiratban, amit a kelet-közép-európai „létező államszocializmus” összeomlása inspirált. $\mathrm{E}$ vita részben új alapokra helyezte a dialógust a marxizmusról és a posztmarxizmusról a geográfiában, részben pedig egy jövőbeni közös baloldali projekt lehetóségeinek újragondolására tett kísérletet.

A kritikai, pontosabban akkor még inkább radikális geográfia a nagyon is releváns kérdéseit a „valós világ” átalakulásából merítette, a kelet-közép-európai változások tanulságait kereste. A „cselekvés és az elkötelezettség” igénye ráadásul abban is kifejezésre jutott, hogy korábban és későbben is ritka kísérletként, ugyanazon vitában az USA és Nagy-Britannia földrajzosai mellett Dániából és Görögországból is véleményt nyilváníthattak. Nagy kár, hogy mi, a vita egyik tárgyát képező keletközép-európaiak, nem lehettünk e párbeszéd aktív alanyai.

Nem tudom persze, hogy keresett-e, s ha keresett volna „baloldali hangokat”, vajon talált volna-e megfelelő vitapartnert az Antipode ebben a régióban. Azt azonban tudom, hogy több mint egy évtizeddel késöbb, amikor helyi szervezỏként invitáltam résztvevőket a Békéscsabán megrendezésre került 3. Nemzetközi Kritikai Geográfiai Konferenciára (közel 150 felhívást szétküldve Magyarországon), még a kis számú, 
Timár Judit: Problémák és perspektívák: „Mi a teendő” a kialakulóban lévő

kritikai geográfia számára Magyarországon? Tér és Társadalom, 17. 2003. 2. 53-65. p.

egy-egy konkrét téma iránt valóban érdeklődő hazai geográfusok mindegyikének első kérdése is az volt: „Mi az a kritikai földrajz?”

Talán önmagában ez a reakció is világossá teszi, hogy e békéscsabai konferencia már csak földrajzi kontextusa miatt is új kérdések felvetésének, s egy esetleges új küldetés megfogalmazásának reményét keltette a Nemzetközi Kritikai Geográfiai Csoport (Painter 2003) számára:

- Az 1997-ben Vancouverben - jelentös helyi támogatói bázisra támaszkodva rendezett alakuló konferencián a kritikai földrajz bizonyos értelemben legitimizálódott és egyértelmüen megfogalmazódott az igény az ilyen geográfia mellett elkötelezettek nemzetközi csoportosulására. A konferencia hatására kiformálódott e csoport célja is: „olyan kutatás és aktivizmus ösztönzése, amely támogatja, a társadalom számára bemutatja és segíti az egyenlőséget megcélzó társadalmi átalakulásra és igazságosságra törekvő politikai küzdelmeket" (Desbines-Smith 1999, 381).

- A 2000-ben Taeguban tartott 2. konferencia, míg alig több mint egy évtizeddel korábban, a katonai diktatúra idején még nem kaphatott volna helyet DélKoreában, ekkorra már egy országosan szervezett csoport aktív közremüködésével kerülhetett megrendezésre. Nem véletlenül juthatott kifejezésre, hogy ,a 'délen' élố kutatóknak nehéz megváltoztatni az 'északon' folyó diskurzust, s az angol nyelv hegemóniája csak fokozza ezt" (Smith 2000, 3). Ezzel pedig egy új feladat is kirajzolódott az ICGG számára. A vélemények és politikák különbözősége ellenére az egységes célrendszer széles körü elfogadása mégis egyértelmủ volt, $\mathrm{s}$ az is világossá vált, hogy a nemzetközi kapcsolatok a kritikai politikával együtt ,erőt és reményt” nyújtanak.

- Békéscsabán mindezzel szemben olyan országban került megrendezésre a 3. Nemzetközi Kritikai Geográfiai Konferencia, ahol legalábbis a kapitalizmus és imperializmus kritikájára irányuló társadalomelméleti megközelítések képviselöi a szintén nem jelentős történelmi távlatban lévő államszocializmus idején nyilvánvalóan egyértelmúbben pozitív befogadó közegre találtak volna, mint ma, amikor az „egyenlőségre törekvő társadalmi változás és igazságosság" elkötelezettjeit az egész régióban nem kis gyanakvás fogadja. Olyan országban gyültek össze e paradigma képviselöi, ahol a kritikai geográfia még csak a megszületés fázisában van.

Ezért ebben a tanulmányban, tökéletesen egyetértve azzal a vancouveri tanulsággal, hogy a tudomány világán belüli aktivizmus önmagában nem elegendö, magyarországi szemszögből nézve mégis ennek fontosságára szeretném felhívni újra a figyelmet, remélve, hogy a hazai tapasztalatok új megvilágításba helyezik a Nemzetközi Kritikai Geográfiai Csoport „belső” tennivalóit is. Magyarországon - és feltehetően számos más poszt-szocialista országban - napjainkban, pl. az USA-tól eltérően, nem a kritikai geográfia és az általa támogatott politikai aktivizmus közti szakadék áthidalása a feladat (Mitchell 2000), lévén, hogy mindkettő mélyponton van. Ahhoz, hogy itt a kritikai geográfia egy ága, a nyugati értelemben vett „népföldrajz projekt" kibontakozhasson és pozitív társadalmi változásokat generálhas- 
son, maga a kritikai geográfia is segítségre szorul. Az alapkérdés tehát, amit e tanulmány vitára bocsát: Milyen teendöje maradt a nemzetközi kritikai geográfia képviselöinek velünk és értünk, kelet-közép-európaiakkal együtt és mindannyiunk érdekében?

A kérdés relevanciájának bizonyítása érdekében először történelmi-társadalmi összefüggésben kísérlek meg néhány lehetséges magyarázatot felvillantani arra a kérdésre, hogy: vajon miért nem bontakozott ki kritikai geográfiai mozgalom Magyarországon? Az okokat azonban nemcsak a szocialista, poszt-szocialista társadalmi-gazdasági környezetben, s nemcsak a magyarországi akadémiai intézményrendszer változásaiban keresem, de a nemzetközi kritikai, illetve korábbi radikális geográfia felelősségét, a kritikai elméletek néhány hiányosságát is felvetem. Végül néhány javaslatot fogalmazok meg az elöttünk álló feladatokra vonatkozóan.

\section{Miért nem volt kritikai geográfia a szocializmus időszakában?}

Mivel a kritikai geográfia hiánya az egész poszt-szocialista közép- és keleteurópai régióra jellemző, a probléma rendszerspecifikus jellege nem kétséges. A társadalmi környezet és a földrajzi tudásanyag mai összefüggésrendszere ezért nem érthető meg a szocializmus időszakának vizsgálata nélkül.

E folyóirat hasábjain nem igényel bővebb kifejtést és magyarázatot, hogy a szocialista államhatalom - hirdetett elveivel szemben - hogyan járult hozzá, illetve teremtett jelentős mérvủ területi egyenlötlenségeket Budapest és a vidék, az ipari tengely és például az Alföld, valamint a városok és a falvak között. A különbségek ,feltérképezése" számos kortárs geográfiai írásban megjelent. Szelényi Iván és Konrád György szociológiai kutatásaiban azonban már arra is rámutatott, hogy a kapitalizmustól eltérően a szocializmus új módon egyenlötlen. Itt a redisztribúció volt az uralkodó integrációs mechanizmus, ez teremtette meg és termelte újra az egyenlötlenségeket, s - a tőkés gazdaság egyenlötlenségi rendszerének „tükörképeként" azokat az alárendelt szerepủ piac korrigálta (Konrád-Szelényi 1969; Szelényi 1983).

A szocializmusnak sem ezek a folytonosan újratermelődő társadalmi-területi egyenlötlenségei, az ezekkel szemben érzéketlen, illetve tehetetlen politikái, sem számos további (nemi, etnikai stb.) problémái nem hívtak életre Magyarországon egy átütő erejủ radikális, illetve kritikai földrajzot. A sztálinista éra diktatúrája alatt ilyen kritikai megközelítésre természetesen egyetlen társadalomtudományi diszciplínának sem volt esélye. A két világháború között (is) „kormánypárti, illetve óvatos reformpárti” emberföldrajz ráadásul a II. világháború után e korábbi „udvari tanácsosi” szerepvállalása büntetéseként „rövid szilenciumra” is kényszerült. Korábbi szerepébe azonban gyorsan visszatalált (Beluszky 1989, 51). A geográfia egyes képviselöi még 5 évvel az 1956. évi forradalom után, tehát már a kádárista korszakban is szerveztek egy olyan, publicitást is kapott vitaülést, ahol Mendöl Tibor humánökológiai alapú városkutatásait érdemi érvek helyett, illetve azokat kisebbségbe szorítva, annak „polgári szemléletéért” bírálták. A marxista településföldrajzot egyértelmúen a funkcionális településszemlélettel azonosítva az ezt képviselő 
Timár Judit: Problémák és perspektívák: „Mi a teendő” a kialakulóban lévő

kritikai geográfia számára Magyarországon? Tér és Társadalom, 17. 2003. 2. 53-65. p.

„Szovjet gyakorlat” követését, s a morfológiai megközelítés elvetését „ajánlották” neki (Abella 1961). Az 1960-as évek társadalmi erjedése által inspirált nyugati marxista, feminista, radikális gondolkodók városi szegénységet, faji diszkriminációt vagy például szegregációt feltáró munkái nem találtak utat a hazai geográfiához. Ha mégis, akkor ezek nem a kelet-közép-európai párhuzamok keresésére sarkallták a földrajzosokat. A világnak ebből a sarkából nézve ezek „nem a mi problémáinknak” látszottak (vagy nem engedték öket annak látszani). Még 1978-ban is megjelent például magyarul olyan, a Szovjetunióból importált cikk, melynek szerzöi úgy írtak a „fejlett tőkés országok" városainak gondjairól, mint a szocializmustól idegen sajátosságokról: „A legnagyobb városokban a kapitalista osztályellentétek, a szegénység és gazdagság közötti különbségek a legélesebben és legleplezetlenebbül nyilvánulnak meg." (Gohman et al. 1978, 80)

Ami kétségtelenül felkeltette a geográfusok társadalmi érzékenységét, az leginkább a falusi települések „hátrányos helyzete” volt, melyről az 1970-es években már jelentősebb számban láttak napvilágot tényfeltáró kutatási eredmények, mint ahogy az országos településfejlesztési politika kritikáját megfogalmazó írások is. Bár, ez utóbbit illetően Beluszky Pálnak (1989) igaza lehetett abban (lévén, hogy a korszak végének munkásságába már magam is bekapcsolódtam, ezért Beluszky kritikáját itt bizonyos értelemben önkritikaként, ezért a korábban mondottakhoz képest kevésbé ,feszengve” fogalmazhatom meg), hogy:

„... a településpolitikai viták kezdetekor, az új fuvallatokat rögvest vitorlájába fogandó, a földrajz buzgón bírálta az OTK gyakorlatát, elveit, a településpolitikát, átvette az opponálók frazeológiáját, ám alig alig tett arra kísérletet, hogy megvizsgálja: a településhálózatban lezajló változások mely elemei táplálkoznak a gazdaság és társadalom átformálódásából, melyek a szándékos beavatkozás eredményei, melyek a gazdasági szabályozás melléktermékei; melyek kívánatosak, melyek küszöbölhetők ki és így tovább. Pedig ez lett volna a kötelessége, még akkor is, ha a nyert eredmények egyike-másika nem is járult volna hozzá pillanatnyi népszerűsége növekedéséhez. Ám a népszerúséget választotta." (Beluszky 1989, 52)

Részben nyilván ezzel is magyarázható, hogy szemben néhány filozófiai, szociológiai tanulmánnyal, ezek miatt az írások miatt nem kerültek a szerzőik komolyabb konfliktusba a hatalommal, s nem váltak társadalmi ellenállást/mozgalmakat ösztönző „szamizdat” irodalom részévé sem. Mindezek folyományaként, az 1990-ben demokratikusan választott országos politikusok közé keruilt történész, filozófus, szociológus kutatók mellöl hiányoztunk mi, geográfusok.

A diktatórikus államberendezkedésen túl, illetve azzal összefüggésben, a kritikai geográfia hiányához az alábbi három körülmény minden bizonnyal hozzájárult:

- A szovjet modellt követve - s ebbe a természetföldrajz dominanciáját is beleértve - a társadalomföldrajzot Magyarországon is a gazdaságföldrajz helyettesítette, ezzel tematikailag erősen leszükítve mind a kutatásokat, mind az oktatást, lelassítva a társadalomföldrajz professzionalizálódását. Erdösi $\mathrm{Fe}$ renc $(1989,82)$ odáig jutott értékelésében, hogy: a „kemény” társadalomtudományok közé ,,bekeveredett ,gazdasági földrajz (= 'a termelőerök területi 
Timár Judit: Problémák és perspektívák: „Mi a teendő” a kialakulóban lévő

kritikai geográfia számára Magyarországon? Tér és Társadalom, 17. 2003. 2. 53-65. p.

TÉT XVII. évf. 2003 @ 2

Problémák és perspektívák ...

elhelyezkedésének tudománya')" még a „Mi - hol - miért?" legalapvetőbb kérdésére is csak „meglehetösen sablonos választ volt képes adni”.

- A földrajzi tudásanyagból, illetve gondolkodásból alapvetően hiányoztak a körïlöttünk lévő világ megértéséhez - pláne megváltoztatásához - elengedhetetlen eszközöket nyújtó elméletek. Ezt a hiányt pedig e folyóirat hasábjain a társadalomföldrajz helyzetéröl folyó vitában résztvevők többsége (Barta 1989; Beluszky 1989; Erdösi 1989; Mészáros 1989) még a rendszerváltás küszöbén is az egyik legsúlyosabb gondként élte meg. A kritikai geográfia kibontakozását gátló tényezők számbavétele szempontjából azonban talán még fontosabb: nem voltak gondolatébresztő tudományos viták társadalomelméletekröl, földrajzi gondolatrendszerekröl, „paradigmákról”2.

- A geográfiát rendkívül erős zártság jellemezte, így azok a kritikai társadalomelméletek, sőt empirikus eredmények sem tudtak behatolni a diszciplína határain, amelyek képesek voltak áttörni a hatalom bástyáit. (A korábbi vita néhány résztvevője a kapcsolatok másik irányát is hangsúlyozta, ezzel a „fogadókészségre" vagy inkább -képességre is utalva, nevezetesen, hogy ,társadalomelméleti felvértezettség" [Beluszky 1989], ,intelligens mondandó" híján [Erdösi 1989], illetve leíró jellege miatt ez a földrajz eleve „érdektelen” is volt a társadalomtudományok számára [Beluszky 1989], nem volt „piacképes a briliánsan fogalmazó társadalomtudományok körében" [Erdösi, 83]).

A kelet-közép-európai földrajz más társadalomtudományi diszciplínákhoz képest is viszonylag tartósabb „mozdulatlansága" részben épp annak a sajátos helyzetének a következménye, hogy a megélhetés érdekében kötött kompromisszumok kiváló eszköze lehetett a ,veszélytelenebb” természetföldrajz védöpajzsa mögé való viszszavonulás. Mivel azonban a ,,(társadalom)elmélethiảny” és a diszciplína zártsága további fontos okokra is rávilágítanak, s a nemzetközi kritikai geográfia számára is tanulságokkal szolgálnak, itt csak ezek továbbgondolására koncentrálok.

A filozófiai pluralizmus és a kritikai társadalomelméletek hiányáért alapvetỏen természetesen maga a szocializmus okolható. Hosszú ideig egyáltalán nem volt tanácsos a marxizmustól (illetve még inkább annak vulgáris változatától) eltérö filozófiai irányzatok felvállalása. Ezért a geográfusok írásaikban vagy a marxizmusra hivatkoztak, vagy ha alternatív intellektuális tradíciók inspirálták öket, akkor arról mélyen hallgattak. Ezt az elhallgatást aztán „sikerült" olyan szintre emelni, hogy egy egész geográfus nemzedék nevelödött ki úgy, hogy egyáltalán nem ismert földrajzi paradigmákat. Így az 1980-as évekre kutatók sora „csempészett be” a magyarországi geográfiába pl. behaviorista vagy humanisztikus elemeket anélkül, hogy akár önmaga - akárcsak e sorok írója - „tudatában” lett volna, vagy tudatosította volna, hogy nem egyszerúen egy új témát vagy módszert adaptált, hanem a korábban elterjedttöl gyökeresen eltérö társadalomelmélethez kapcsolódott. Ezért a helyzetért azonban mégsem csupán a társadalmi rendszer tehetỏ felelössé, hanem magának a diszciplínának a történetileg kialakult pozíciója is, hiszen filozófusok és szociológusok egy csoportja szembeszállt a korlátokkal, olyan elméleti kutatásokat 
Timár Judit: Problémák és perspektívák: „Mi a teendő” a kialakulóban lévő

kritikai geográfia számára Magyarországon? Tér és Társadalom, 17. 2003. 2. 53-65. p. 58 Timár Judit

TÉT XVII. évf. 2003 a 2

végzett, melyekért az 1970-es évek elején konzervatív irányba mozduló politikai légkörben emigrációra kényszerült.

Tanulságos lehet például Szelényi lván esete, aki Konrád Györggyel az 1960-as évek végén végzett - a geográfiához igen közelálló - városszociológiai empirikus kutatásaiban a szocialista redisztribúció eredményeként született, ijesztő társadalmi egyenlőtlenségeket tárt fel, és magát a polgári, értékmentes, empirikus társadalomtudomány elkötelezettjének tekintette. A weberi „,megértő társadalomkutatás” eszméjét követve, a politikai programkészítést, az értékválasztásokat kizárta a tudományos megismerés köréböl (Szelényi 1990). Későbbi amerikai emigrációjából visszatekintve mégis úgy látta, nem ő. volt az ,ideális 'áldozati bárány' az uralkodó kultúrpolitika szemében":

„Ök az ideológiai tisztítótüzet a 'revizionisták' ellen készítették elö; természetes ellenségeik a Lukács-iskola revizionista, kritikai marxistái voltak, akik egy nemes marxi szocializmusképet kértek számon a 'létező szocializmusok' nem különösebben nemes vagy vonzó valóságától. Az akkori kultúrpolitika igazi ellenfélként a kommunista-szocialista hagyományból építkezö ideológiai kritikusokat tekintette: Heller Ágnest, Fehér Ferencet, Vajda Mihályt, Márkus Györgyöt, Kis Jánost, Bence Györgyöt vagy Haraszti Miklóst. ... A polgári pozitivizmus elfogadhatóbbnak tetszett a hatalom akkori birtokosai szemében, mint a lukácsi ihletésü kritikai marxizmus." (Szelényi 1990, 435)

Mindezek továbbgondolása alaposan megfontolandó tanulságokkal szolgál a nemzetközi kritikai geográfia számára is: a fennálló társadalmi rend elleni szemlélet önmagában „kevés”. Ha kutatásainkat valóban a társadalmi változások igénye vezérli, végérvényesen meg kell szabadulnunk a - még számos helyen jelen lévö (Ramírez 2003) - pozitivizmus béklyójától.

Más kérdés, hogy a szocializmus diktatórikus hatalomgyakorlása már a weberi megértő társadalomkutatás bizonyos eredményeit is betiltandónak ítélte. Végül 1975-ben a rendőrhatóságok nyomása alatt Szelényi is nyugatra vándorolt. Erre a lépésre a perbe fogott társadalomtudósok melletti kiállásán kívül saját bevallása szerint „egyre szemtelenebb” írásai miatt is rákényszerítették. A szocialista társadalmi egyenlötlenségekre, a szocializmus redisztributív gazdasági rendszerére, új osztályviszonyainak elemzésére irányuló empirikus indíttatású kutatásai a kultúrpolitika, illetve pártbürokrácia számára elfogadhatatlanná váltak. Konráddal írt könyve, „Az értelmiség útja az osztályhatalomhoz” ugyanúgy nem jelenhetett meg, mint pl. a Kemény István szociológus által indított szegénységkutatások vagy a devianciavizsgálatok eredményei. Nyilván nem véletlen, hogy ezek a társadalomtudományi munkák a nyolcvanas évekre olyan illegálisan múködő politikai mozgalmak indítását inspirálták, mint a Szegényeket Támogató Alap (SZETA) vagy a Beszélő Kör.

Szegénység, deviancia, ,hátrányos helyzetbe szorított osztályok” tehát a kommunista ideológiába nagyon is bele nem illő, betiltandó fogalmakká váltak. A kritikai geográfusok számára azonban újabb tanulságot jelenthet, hogy a társadalomföldrajz fogalomrendszerével ugyanekkor leírt ,hátrányos helyzetü falvak" problémaköre nem látszott a hatalom számára veszélyesnek, hiszen az kívül állt az (ortodox) marxizmus koncepcióin, elméleti keretein. Az a nyugati marxista geográfia viszont, amely épp 
Timár Judit: Problémák és perspektívák: „Mi a teendő” a kialakulóban lévő

kritikai geográfia számára Magyarországon? Tér és Társadalom, 17. 2003. 2. 53-65. p.

TÉT XVII. évf. 2003 - 2

Problémák és perspektívák ...

59

ebben az időszakban, mindenekelőtt Harvey (1973) jóvoltából már beillesztette a geográfiai kérdések tanulmányozását ebbe a rendszerbe, a kapitalizmus különböző földrajzaira koncentrált. Ez a nyugati marxista geográfia is távol maradt azonban a kelet-európai országok létezỏ szocializmusának alapos vizsgálatától, bírálatától; jövöképében nem tudott mit kezdeni ezzel a problémakörrel. Ráadásul - főleg angol-amerikai meghatározottságából adódó - alapvetően városi fókusza kevés támpontot adhatott e sokkal jellemzöbben rurális, s a szegénységet is elsösorban ebben a dimenzióban (nem az urbánusban) megélt társadalmaknak. A lecke máig ható: a nemzetközi kritikai geográfiának az akadémiai aktivizmus terén is bőven van feladata. Nemzetközi összefogása nemzetközi szolidaritást is kell, hogy jelentsen kutatásaiban. Ha pedig figyelembe vesszük, hogy a kortárs magyar szociológia eredményei politikai aktivizmust is képesek voltak segíteni, akkor a tét még sokkal nagyobb, s e szolidaritás sokkal szélesebb értelmet és jelentőséget kap.

\section{Miért nem indult el egy kritikai geográfiai „mozgalom” a poszt-szocializmusban?}

Nem kétséges: a jelenlegi poszt-szocializmusban, ha azon rajta is vannak még az átmeneti társadalom jellegzetességei, a téralkotás ("production of space") mechanizmusa már nem különbözik alapvetően a fejlett kapitalizmus hasonló folyamatától. Az egyenlötlen területi fejlödés - mint a kapitalizmus törvényszerüsége -, annak összes társadalmi problémájával, valamennyi földrajzi léptékben megnyilvánuló, szemünk előtt zajló valóság.

Napjaink hazai társadalom-földrajzi kutatásai nem maradtak érzéketlenek e releváns kérdések iránt. A területi egyenlőtlenségek, falusi problémák vizsgálatának folytatása mellett például megjelentek a városi elszegényedésre, migrációra, munkanélküliségre, a termelés mellett a társadalmi újratermelés egyenlőtlenségeire irányuló publikációk is. Nyilván nem véletlen azonban, hogy amíg a New York-i Tompkins Square park 1988-as demonstrációján diákok, helyi lakosok, aktivisták, hajléktalanok és lakásfoglalók többek között azt skandálták, hogy ,,a dzsentrifikáció népirtás" (Smith 1991), addig a mai budapesti lakásfoglalások és kilakoltatások során sem a médiában, sem az érintettek szájából nem hangzik el e dzsentrifikáció városföldrajzban oly fontos - kifejezés, hiszen valószínúleg sosem hallottak róla. A felelösségünk vitathatatlan: a városi szegregáció egyszerü feltérképezése - most már nem a hatalom, de az egész társadalom számára - nyilvánvalóan sokkal kevésbé releváns kérdés, mint azok a gazdasági és politikai folyamatok, amelyek ilyen egyenlőtlen geográfiai viszonyokat teremtenek. Azoknak viszont, akik már megpróbáltuk vizsgálni ezeket a „mozgatóerőket”, azt a tanulságot kell megvonnunk, hogy nyilvánvalóan nem tudtuk még a nyugati kollegákhoz hasonlóan közvetíteni eredményeinket a társadalom, az „utca embere” számára. Azon is el lehet gondolkozni, hogy vajon a nemzetközi geográfiának már „csak” a „fö áramlatára” jellemző térfetisizmust (a tér pusztán ,tartályként” kezelését) vajon mennyiben sikerült túllépni, $\mathrm{s}$ az alternatív földrajz felé fordulókra jellemzően a téranalíziseket ,társa- 
Timár Judit: Problémák és perspektívák: „Mi a teendő” a kialakulóban lévő

kritikai geográfia számára Magyarországon? Tér és Társadalom, 17. 2003. 2. 53-65. p.

dalmasitani". Még ha vannak is erre pozitiv kísérletek - úgy vélem -, azokról sem mondható még el, hogy - Neil Smith $(1990,160)$ szóhasználatával élve - a teret alapvetöen társadalmi ,mély térnek" ("deep space") tekintik. Olyannak, ami a „Henry Lefevbre 'téralkotás' [production of space] koncepciójába illö tér, annak leggazdagabb értelmében." Talán leginkább azért nem, mert írásainkkal még meszsze nem közvetítjük - de legalábbis nyíltan nem mondjuk ki -, hogy a tér a kontrollnak, uralkodásnak, hatalomnak is egy eszköze (Lefebvre 1991).

Úgy tưnik tehát, hogy a poszt-szocializmus időszakának magyarországi geográfiai kutatásai témaválasztásukban már komoly lépéseket tettek a kritikai geográfia irányába. Ha azonban többek között Neil Smith (2003) vagy Don Mitchell (2003) e folyóirat hasábjain is kifejtett véleményével értünk egyet, s a kritikai geográfiától jóval többet (jövőképet, társadalmi egyenlötlenségek felszámolása melletti elkötelezettséget, aktivitást stb.) várunk el, mint „egyszerü” bíráló hozzáállást, akkor ez még csak a legelső lépés. Többségůkben ugyanis még e szociális érzékenységet tükröző munkák is inkább a pozitivista, értékmentes, empirikus társadalomkutatás reprezentánsai - radikális fơldrajzról pedig egyáltalán nem beszélhetůnk. A magyarázatot keresve itt csupán néhány egyértelmú összefüggésre próbálok rávilágítani:

1) A kritikai geográfia kibontakozásának talán legfontosabb gátja a posztszocializmusban a baloldaliság felvállalásának nehézsége. A másutt terjedō, e régióban a szocializmus alatt elnyomott neokonzervativ és neoliberális ideológiák hirtelen nagy vonzerőt gyakoroltak az átmenet országaira, míg a baloldalisághoz a kudarcként vagy „ellenségként” megélt államszocializmus képe tapad. A diktatórikus állam „megkerülésének”, illetve ,becsapásának” évtizedekig tartó össznemzeti ,játéka" után-melyben a legkuilönfélébb politikai erỏk múködtek együtt - a végre demokratikusan kialakított új államberendezkedés - különösen baloldali - bírálata kifejezetten frusztrációt okozott az értelmiség egy része számára. Egyetértek Szalai Erzsébet (2002) szociológussal, aki szerint a politikai baloldallal messze nem azonos eszmei-ideológiai baloldalnak a szavát hallató része marginális helyzetü és jelentỏségü, még akkor is, ha a „rejtôzködő” baloldali értelmiség köre ennél jóval tágabb. Témánk szempontjából különösen elgondolkodtató, hogy az általa felsorolt ismert baloldali gondolkodók közt egyetlen geográfus neve sem szerepel.

A plurális demokrácia kiépítéséhez létre kellett hozni a politikai pártokat, aminek egyik következményeként a pártpolitika ma átszövi az élet számtalan szféráját. A rendszerváltó országok pártpolitikájában ráadásul az átlagnál is sokkal jobban összekuszálódik, illetve nem következetesen képviselt a balés a jobboldali ideológia. Más országoktól eltérỏen Magyarországon például a globalizáció vagy az afganisztáni háború elleni tiltakozás jószerével csak a szélsőjobboldali nacionalista pártra korlátozódott. Egy másik példa: a legutóbbi választáson a szocialista pártot a lekőszönő jobboldal a „kommunista pártállami gyakorlat" visszacsempészésével éppúgy vádolta, mint a nagytőke védelmezésével. Ilyen körülmények közơtt e régióban a születőben lévỏ kritikai geográfia kevéssé tud „egyenlőséget megcélzó társadalmi átalakulásért 
és igazságosságért küzdő, imperializmus, elnyomás elleni vagy környezeti igazságosságért harcoló mozgalmak" mellé állni. A résztvevők és ellenzők aktuálpolitikai, és nem ideológiai alapon - folytonosan változó tábora miatt itt egyelöre konkrét ügyeket lehet támogatni, ilyenek mellett lehet mozgósítani.

2) A rendszerváltás után megnött társadalmi polarizáció és elszegényedés ellenére ma rendkívül alacsony szintủ a társadalmi szolidaritás, $\mathrm{s}$ - részben a fentiekkel összefüggésben - nagyon kezdetleges szinten van a civil társadalom szervezettsége; az átfogóbb társadalom-átalakítási célokat szem előtt tartó, alulról induló kezdeményezések legalábbis alig léteznek. A mindkét oldalon jellemzỏ alulreprezentáltság miatt nemcsak a kritikai geográfia nem tudja támogatni az ilyen mozgalmakat, de azok sem képesek inspirálni a földrajzot. Nyugati értelemben vett „népföldrajzról” itt még aligha beszélhetünk (G. Fekete 2003). Ehhez egyrészt hiányoznak a térfolyamatok társadalmigazdasági meghatározottságát megmagyarázni képes elméletek. A sajátosságainkra hivatkozók közül sokan „kritikátlan másolásnak” tartják a fokozatosan beáramló nyugati elméletek átvételét. Az átmenet körülményeire értelmezett, abban eligazítani képes „saját” elméleteket viszont még az ilyen véleményt képviselők sem dolgoztak ki.

Mindemellett nem indult el a földrajzi kutatási eredmények "népföldrajzban" nélkülözhetetlen popularizálása (Mitchell 2000). Ez persze összefüggésben van a geográfiában is jelen levö - Próbáld Ferenc által már az 1989-es vitában is erősen kritizált - „az ismeretterjesztés feladatát rangon alulinak tekintő" "tudományos sznobizmussal", ami miatt a társadalomföldrajzi ismeretek nem tudnak benyomulni a szélesebb értelemben vett köztudatba, s szakadék tátong az iskolai földrajzoktatás és a tudományos tevékenység között (Próbáld 1989, 78). Az interaktivitásra törekvő módszerek alkalmazása, a világot nemcsak megérteni, de valóban megváltoztatni próbáló kutatói aktivitás pedig jószerével csak az elmaradottság ellen küzdő kistérségi civil szerveződéseket ( $G$. Fekete 2003) s bizonyos feminista szervezeteket támogató vizsgálatokhoz kapcsolódva jelenik meg.

3) Az alkalmazott geográfia szerepének problémái, még ha napjainkban felfokozottak is, korántsem új keletủek. Beluszky Pál (1989) már a rendszerváltás előestjén a társadalomföldrajz „udvari tanácsosi” szerepét ostorozta. Erdösi Ferenc $(1989,85)$ szintén akkori értékelése szerint: „Régi gond, hogy KeletKözép-Európában az establishment nem udvari bohóc (= kritikus), hanem lakáj (= fejbólogató, hozsannázó) szerepben látja legszívesebben a tudomány képviselöit." Pomázi István $(1989,86)$ viszont azt jegyezte meg, hogy ő még az „udvari bolond” szerepet sem hajlandó felvállalni, hisz ez ,a hatalom kizárólagos szórakoztatását jelentené". Az alkalmazott geográfia ráadásul az 1990-es években hirtelen piaci viszonyoknak kitett egyetemeken, s különösen az akadémiai kutatóintézetekben, látványosan elöretört. A piaci verseny viszont elsősorban az állami, s egyelöre jóval kisebb részben a magáncégek számára legjobban hasznosítható technikai és praktikus tudást (illetve kép- 
Timár Judit: Problémák és perspektívák: „Mi a teendő” a kialakulóban lévő

kritikai geográfia számára Magyarországon? Tér és Társadalom, 17. 2003. 2. 53-65. p.

zést) preferálja. A tudománytól elvárt filozófiai-politikai semlegesség azonban még a közszféra által megrendelt geográfiai elemzésekkel, prognózisokkal szemben is gyakran csak látszatigény, hivatkozási alap a nagyon is elkötelezett hatalmi érdekek szerinti felhasználásban, végrehajtásban, nem is beszélve a bevallottan is ilyen indíttatású prekoncepciók igazolására kért „alkalmazott kutatásokról". Nagyon is egybevágnak a poszt-szocializmusban szerzett tapasztalatok a David Harvey $(1984,7)$ által már két évtizeddel ezelött megvont konzekvenciákkal: „Önmagunk eladása a kormánynak egy meglehetősen kétértelmủ vállalkozás, ami elvész valamiféle misztikus 'közérdek' mocsarába egy olyan világban, amit krónikus hatalmi kiegyensúlyozatlanság és versengö követelések jellemeznek". Nagy kérdés, hogy mindennek tudatában hogyan mủvelhetünk kritikai földrajzot munkaidönk egyik részében, amikor a másik felében a hatalmi érdekek által uralt állami, vagy a profit növelésére törekvő magánszféra számára müvelünk alkalmazott geográfiát.

4) Az EU-csatlakozáshoz elengedhetetlen regionális tervezés felértékelődése lendületet adott Magyarországon is a regionális tudomány térnyerésének. Nem véletlen, hogy a fent elemzett társadalmi-gazdasági környezetben a Regionális Kutatások Központja - a 3. Nemzetközi Kritikai Geográfiai Konferencia házigazdája - sem egyedülálló interdiszciplináris jellegében látta az intézményesülési harcához szükséges erőt, hanem „saját” diszciplínájától, azaz a regionális tudománytól remélte az ígéretes jövöt. Az ily módon különösen éles versenyhelyzetbe szorított társadalomföldrajz viszont így legalább tudományelméleti kérdésekkel foglalkozó diszciplinaközi vitákra kényszerült (Nemes Nagy 2001). Ezekben, vagy például a szegedi Magyar Földrajzi Konferenciának e sorok írója által megtapasztalt némely vitájában azonban úgy túnt, makacsul tartja magát egy olyan vélemény, amely ,a diszciplínahatárok védelmében" kizár a társadalomföldrajzból nyugaton széles körben elterjedt „puha módszereket”, illetve bizonyos témákat; a „tudományosság” követelményének tekinti az értékmentességet; az objektivitás védőbástyája mögé bújtat messze nem objektív földrajzi magyarázatokat, $\mathrm{s}-$ az eltérő álláspont felvállalása, illetve kifejtése helyett - úgy tesz, mintha nem is létezne Donna Haraway fél világot bejárt, s természetesen hatalmas vitát kavart „szituációba ágyazott tudás" elmélete.

Ilyen helyzetben talán éppen az adhatna optimizmusra okot, hogy pl. az amerikai radikális földrajz az 1960-as években - bár teljesen más társadalmi környezetben - részben épp az eluralkodott pozitivizmus tagadásából nőtt ki. Sokkal reményteljesebb viszont, hogy a nyitottá és egyszerübbé vált kommunikáció - s egy nyelveket ismerö, utazó fiatal nemzedék - révén a nemzetközi kritikai geográfia eredményei már szinte akadálytalanul utat találhatnak a régióba, így Magyarországra is. A társadalomelméleteket alapvetően továbbra is nélkülözö itteni geográfia képviselöinek azonban nem könnyủ az eligazodás a kritikai földrajz egyébként befogadó jellegét tükröző eklekticizmusában. A témagazdagság vonzásának nagyon is érzékelhetőek a hatásai 
a nagyrészt fiatalok által indított új kutatásokban. Hogyan lehet azonban tudatosan választani a kritikai földrajzban jelen levô olyan elméleti megközelítések között, mint az anarchizmus, „környezetvédelmi elmélet” (environmentalism), feminizmus, marxizmus, poszt-marxizmus, poszt-kolonializmus, posztstrukturalizmus, pszichoanalízis és a szükebb értelemben vett kritikai elmélet (Johnston et al 2000), amikor ezek értelmezése hiányzik az egyetemi oktatásból, s geográfiában való alkalmazásukról magyarul még csak egyetlen - s csupán néhányukat érintö - útbaigazító könyv látott napvilágot (Mészáros 2000).

\section{Mi a teendö?}

Mindezek után talán nyilvánvaló, hogy a „Milyen teendőnk maradt?” kérdést kelet-közép-európai szemmel nézve én is csak azokhoz csatlakozhatom, akik szerint: sok minden.

Magyarország, de valószínủleg egész Kelet- és Közép-Európa épp csak nyiladozó kritikai földrajzának megerősítése érdekében talán az a legnehezebb feladat, hogy egyszerre vértezzük fel az itteni geográfiát társadalomelméletekkel, és „tanuljuk meg” úgy popularizálni a földrajzi tudást, hogy az valóban „az emberekért, ne csak értünk" legyen (Mitchell 2000), kapcsolatot találva azokkal a civil szervezetekkel, amelyeknek céljait támogatni akarjuk. Ezzel pedig a legjobb útját választhatnánk saját aktivizmusunk megkezdésének, illetve megerősítésének. E célok elérésében azonban nagyon is sokat segíthet az ICGG:

1) Az elméleti megalapozottsághoz, de általában véve az ICGG céljaival való azonosuláshoz Kelet-Közép-Európából nézve kevés támpontnak látszik az „egyenlőségre törekvő társadalmi változás és igazságosság” iránti elkötelezettség. „Hátunk mögött” a szintén egalitáriánus elveket hirdető államszocializmussal, ez a végcél önmagában még ,homályos”, s így olyanok számára is szkepticizmusra adhat okot, akik különben érdeklődést mutatnak a kritikai földrajz iránt. Nagy szükség lenne egy ennél sokkal kidolgozottabb jövőkép megfogalmazására: pontosan milyen társadalmi-gazdasági viszonyok és hatalmi berendezkedés keretei között, milyen fontos kérdésekben kellene társadalmi konszenzust elérni, és milyen intézményrendszerrel lehetne azt megvalósítani stb.?

2) Nem halogatható az átmenet sajátos körülményeire is érvényes átfogó elméletek megalkotása. Ehhez elsősorban a poszt-szocialista országok kritikai geográfusainak kellene a „,nyugat felé fordulás” évtizede után egymásra találniuk. Bár erre a társadalomföldrajz néhány területén már vannak kiváló kezdeményezések, azt még az országon belül sem igazán tudjuk, kik is próbálnak vagy szeretnének kritikai földrajzi kutatásokat végezni, ezzel az irányzattal azonosulni. A kapitalizmus globalizáció körülményei között való kiépítésének korszaka viszont mindenki számára tanulságokat hordoz, ezért valóban kölcsönös haszonnal járhatnának a kelet-nyugati, de csakis a Nicky Gregson, Dina Vaiou és Kirsten Simonsen (2003) által kipróbált, és a konfe- 
Timár Judit: Problémák és perspektívák: „Mi a teendő” a kialakulóban lévő

kritikai geográfia számára Magyarországon? Tér és Társadalom, 17. 2003. 2. 53-65. p.

rencián vitára is bocsátott, kultúrák közötti, egyenrangú együttmủködéssel megvalósított kutatások.

3) A „népföldrajz” egyfajta kiterjesztésének is tekinthetnénk, ha a „helyünkbe jönne" a nemzetközi kritikai földrajz. Ennek a viszonylag új geográfiai szemléletnek és gyakorlatnak a hazai terjesztésére sokkal nagyobb esély lehetne, ha különösen a nemzetközi folyóiratokban már izgalmas, inspiráló vitákat kiváltott külföldi kritikai geográfusok eljuttatnák a nem feltétlen „rólunk”, de kifejezetten ,nekünk” szánt írásaikat a $m i$ folyóiratainkba. Ebben, a békéscsabai konferencián közvetített kérésben már - ha nem is könnyen - megszületett az első eredmény, nevezetesen a Tér és Társadalom jelen száma.

\section{Jegyzetek}

1 A tanulmány a 3. Nemzetközi Kritikai Geográfiai Konferencián, Békéscsabán 2002. június 25-én elhangzott nyitó plenáris ülés elöadására épül, a hazai viszonyok részletesebb kifejtésével.

${ }^{2}$ Fontosnak tartom itt hangsúlyozni, hogy annak a föntebb idézett, közel másfél évtizede zajló vitának a résztvevői is - bár Beluszky Pál (1989) tett utalást arra, hogy a „földrajz kimarad”” a társadalomtudományok „eszmeáramlataiból”, illetve, hogy adós maradt többek között „irányzatok, módszerek” mérlegre tételével - az el méletek hiányát, s nem a paradigmák megismertetésének és ütköztetésének elmaradását kifogásolták. Jómagam számos ponton egyetértek az ỏ társadalomföldrajz egészérổ felállított látleletükkel - az általuk felvázolt problémák jelentös része a kritikai geográfia kibontakozásának is akadályt állított. Hogy akaratuk ellenére, illetve a megkérdezésủk nélkül mégse keltsem azt a hatást, mintha az egyetértés kölcsönös lenne, meg kell jegyeznem, hogy bár épp az eszmeáramlatok elmaradt vitái miatt korántsem vagyok biztos abban, hogy ook a nagy földrajzi gondolatrendszerek közül pontosan melyeket képviselik, mégis elképzelhetönek tartom, hogy - „visszafelé” - közülük esetleg többen sem tudnak azonosulni magával a kritikai geográfiával, aminek az elterjedését e cikkben szorgalmazni próbálom.

\section{Irodalom}

Abella M. (1961) Ankét a településföldrajz helyzetéröl és feladatairól. - Földrajzi Értesítő. 1. 121-127. o. Barta Gy. (1989) A földrajz válsága nemcsak magyar jelenség. - Tér és Társadalom. 2. 80-82. o.

Beluszky P. (1989) Magánjelentés a (társadalom) földrajzról. - Tér és Társadalom. 1. 49-63. o.

Desbines, C.-Smith, N. (1999) The International Critical Geography Group: forbidden optimism? Enviroment and Planning D: Society and Space. 18. 379-382. o.

Erdösi F. (1989) A földrajz tekintélyhiányának néhány okáról. - Tér és Társadalom. 2. 82-86. o.

G.Fekete É. (2003) Peoples geography (,népföldrajz") - a kritikai geográfia új irányzata. - Tér és Társadalom 2. 67-77. o.

Gohman, V.M.-Lappo, G.M.-Majergojz, I.M.-Masbic, J.G. (1978) Az urbanizáció földrajzi problé mái a különbözó társadalmi rendszerü országokban. - Földrajzi Közlemények. 26. 69-83. o.

Gregson, W.-Simonsen, K.-Vaiou, D. (2003) Writing (across) Europe: on writing spaces, and writing practices. - European Urban and Regional Studies. 1. 5-22. o.

Harvey, D. (1973) Social Justice and the City. Johns Hopkins University Press, Baltimore.

Harvey, D. (1984) On the history and present condition of geography: an historical materialist manifesto. - Professional Geographer. 36. 1-11. o.

Johnston, R.J.-Gregory, D.-Pratt, G.-Watts, M. (eds.) (2000) The Dictionary of Human Geography. Blackwell, Oxford.

Konrád Gy.-Szelényi I. (1969) Az új lakótelepek szociológiai problémái. Akadémiai Kiadó, Budapest. Lefebvre, H. (1991) The production of space. MA, Blackwell, Oxford and Cambridge.

Mészáros R. (1989) Mérföldkő vagy temetés? - Tér és Társadalom. 2. 75-77. o.

Mészáros R. (2000) A társadalomfóldrajz gondolatvilága. Szegedi Tudományegyetem Gazdaság- és Társadalom-földrajzi Tanszéke, Szeged. 
Mitchell, D. (2000) The Peoples Geography Project: Popularizing Radical Geography. - $2^{\text {nd }}$ International Critical Geography Conference. For Alternative 21 Century Geographies. vol. 2. Korean Association of Spatial Environment Research, Taegu. 31-40. o.

Mitchell, D. (2003) Kritikai geográfia: kritikus bukás, kritikus siker. - Têr és Társadalom. 2. 83-86. o.

Nemes Nagy J. (szerk.) (2001) Geográfia az ezredfordulón. - Regionális Tudományi Tanulmányok 6. ELTE Földrajz Tanszékcsoport, Budapest.

Painter, J. (2003) A Nemzetközi Kritikai Geográfiai Csoport. - Tér és Társadalom 2. 79-81. o.

Pomázi I. (1989) Miért beteg a magyar társadalomföldrajz? - Tér és Társadalom. 2. 86-91. o.

Próbáld F. (1989) Extra Hungariam non est vita? - Tér és Társadalom. 2. 77-80. o.

Ramírez, B. (2003) A kritikai földrajz gyakorlata: különböző kihívások különbözỏ kontextusokban. Tér és Társadalom. 2.93-97. o.

Smith N (1990) Uneven Development: Nature, Capital and the Production of Space. MA, Blackwell, Oxford and Cambridge.

Smith N. (1991) Tompkins Square Park Time Line. - Wodiczko, K. (ed.) New York City Tableaux: Tompkins Square. The Homeless vehicle Project. Exit Art, New York. 14-21. o.

Smith, N. (2000) Conference Report. http://econgeog.misc.hit-u.ac.jp/icgg/intl_mtgs/taegu2000.html

Smith, N. (2003) Jelszavak és könyörtelen kritika: marxizmus és a nemzetközi kritikai geográfia. Tér és Társadalom. 2. 37-51. o.

Szalai E. (2002) Baloldal - új kihívások elótt. - Népszabadság. július 6.

Szelényi, I. (1983) Urban Inequalities Under State Socialism. Oxford University Press, Oxford.

Szelényi I. (1990) Uj osztály, állam, politika. Európa Könyvkiadó, Budapest.

Walker, D. (1989) What's left to do? - Antipode. 21. 133-165. o.

\section{PROBLEMS AND PERSPECTIVES: "WHAT'S LEFT" FOR EMERGING CRITICAL GEOGRAPHY TO DO IN HUNGARY?}

\section{JUDIT TIMÁR}

The question of "What's left to do?" was asked by Dick Walker in 1989 sparking off an exciting debate in Antipode inspired by the collapse of state socialism in Central and Eastern Europe. On the one hand, the debate provided a new base for the dialogue on Marxism and post-Marxism in geography; on the other, it attempted to reconsider the possibilities of a future collective leftist project, on the other. It is a great pity that Central and Eastern Europeans, the subject matter of the debate, could not participate actively in that dialogue. It is doubtful, whether Antipode would have been able to find the right partners of "leftist voices" in this region. What seems to be certain is that in 2002, the $3^{\text {rd }}$ International Conference of Critical Geography in Békéscsaba was hosted by a country where critical geography was just being born.

The basic question of the present paper is "What's left for international critical geography to do for us and with us in Central and Eastern Europe?" To prove the importance of the question, the paper begins by providing a historical perspective on the question of why a critical geography "movement" failed to evolve in Hungary. In confronting this question, the paper then looks not only to socialist and post-socialist socio-economic environment and the changes in the academic institutional system, but also to the responsibility of international critical geography. Finally, the paper concludes by putting forth a few proposals concerning the tasks that critical geographers face. 